\title{
Measuring Exterior Safety of Canadian Residential Neighbourhoods
}

\author{
Alan G. Phipps', Barry A. Horrobin² \\ ${ }^{1}$ Department of Sociology, Anthropology and Criminology, University of Windsor, Windsor, Canada \\ ${ }^{2}$ Windsor Police Service, Windsor, Canada \\ Email:phipps@uwindsor.ca, bhorrobin@police.windsor.on.ca
}

Received 20 April 2014; revised 26 May 2014; accepted 4 June 2014

Copyright (C) 2014 by authors and Scientific Research Publishing Inc.

This work is licensed under the Creative Commons Attribution International License (CC BY).

http://creativecommons.org/licenses/by/4.0/

(c) (i) Open Access

\begin{abstract}
A safety audit measures the safety of 36 exterior attributes of properties and streets in a low-density residential neighbourhood in terms of four principles of modern crime prevention through environmental design, namely, territoriality, natural surveillance, activity support and access control. Eighty-three residents have walked around each of their small neighbourhoods, and audited the safeties of its area, individual private properties, and adjacent area in daylight; and the safeties of its area, properties, and exterior lighting in darkness. Findings are that older-urban neighbourhoods' overall safety percentages and attribute safeties in daylight and darkness were consistently lower than those in newer suburban, rural or small-town ones; and frequently lower than those in newer-urban neighbourhoods, or older suburban, rural or small-town ones. Recommendations are about improving 12 less safe or unsafe attributes by means of physical planning and environmental design. Also having identified those attributes, we speculate about replicating the safety audit via online Street Views of existing Canadian neighbourhoods.
\end{abstract}

\section{Keywords}

Crime Prevention through Environmental Design (CPTED), Safety in Low-Density Residential Neighbourhoods, Safety Audit Survey, Canada

\section{Introduction}

Natural and built environments may have some conditions in the form of attributes that make residents feel safe when they are outside in their residential neighbourhood in daylight or darkness, or both; while other attributes may make them feel unsafe [1] [2]. Safe and unsafe attributes are inferred in this study from 83 residents' safety audits of their immediate neighbourhoods, where they surveyed the safeties of 36 exterior attributes of proper 
ties and streets in daylight, darkness, or both. Safeties of these exterior attributes of low-density homes on conventional streets are measured in terms of whether they did or did not promote four components of modern principles of crime prevention through environmental design (CPTED), namely, natural surveillance, territoriality, access control and activity support [3]-[6].

The genesis of this study is what the practitioner of the two authors (B.A.H.) has been able to do-but has not done-during his more-than-twenty years of crime prevention with these CPTED principles especially in Windsor, Ontario, Canada. On the one hand, he has theorized these principles for improving residents' levels of safety, comfort, and wellbeing within neighbourhoods [7]. For example, good natural surveillance should promote a sense of accountability with exposure in open, visible view corridors. Similarly, strong territoriality, for example, with upkeep of property and border definition between public and private spaces, should translate into residents' having more confidence they are in care and control of the environment, and not someone intent on committing a crime. Strong territoriality should also help access control that limits intrusion by lawbreakers, by means of clean and clear streets, and lighting at key locations. Plus, positive activity generators should encourage social interaction among residents and visitors, with local park amenities and community gathering places also serving to discourage antisocial behaviours from becoming routine.

On the other hand, this practitioner has rarely applied these CPTED principles for measuring and evaluating the safety of properties and streets in ordinary existing low-density residential neighbourhoods (e.g., [8]); and he is unaware of anybody who had done this in Canada. Instead, he has more frequently recommended building and/or environmental alterations based upon CPTED principles for interiors and exteriors of high-rise apartment buildings (e.g., [9] [10]), and medium-density public housing projects (e.g., [7]). Moreover, his evaluations of low-density residential neighbourhoods have more frequently been about possible safety impacts of building higher-density apartment buildings in those neighbourhoods (e.g., [11]), or of having medium-density public housing projects located adjacent to them (e.g., [12]). Why has this expert practitioner been so rarely asked to audit ordinary existing low-density residential neighbourhoods for safety issues? One (implausible) reason for no need to ask him in the past may be if those types of neighbourhoods have few safety issues. Another (practicable) reason for no need to ask him in the future may be if residents can do this safety auditing by themselves.

This study's contribution therefore is not only in using modern CPTED principles for defining and testing potentially safe and unsafe attributes of built and natural environments of single-detached houses, duplexes, townhouses and/or low-rise apartment buildings, located on conventional grid or curvilinear streets. Its contribution is also in designing a safety audit for residents' surveying the exterior safeties of homes and neighbourhoods, as opposed to this being done by non-residents including experts as in another study [13]. Residents' surveying should be more sensitive than a visitor's surveying would be to local safety issues on streets and around properties in daylight and darkness [5] [14] [15]. Personal experience of a study neighbourhood should also insulate their surveying from others' possibly biased reputations of the neighbourhood as a place to live [16].

Residents' own survey findings may curb CPTED experts from imposing their recommendations of how to manage risks for a safer neighbourhood [17] [18]. For example, an expert in another study did on-site evaluations of exterior CPTED components in advance of residents' self-administering a questionnaire about their fear of crime and victimisation experiences [19]. Police officers in another study evaluated single detached houses' vulnerability to burglary by rating fifty-five environmental cues that they could see on photographs [20]. An expert in another study rated eleven indicators of defensible space within a 200-yard radius of telephone kiosks [21].

Either way, a single trained resident in this study, or experts in other studies, will have been rating the safeties of attributes of a neighbourhood on behalf of others [22]. Some residents may care less about safety outside the home if they are not involved in their neighbourhood, and are not committed to life and activity there [23] [24]. Many residents nowadays perceive their modern neighbourhood as a community of limited liability [25]. They may have relatively few social interactions with neighbours, and possibly only then for strategic family or business reasons.

Nonetheless, even homebodies should have a cognitive boundary of their local residential area within which they are more acquainted with residents than those outside of it [26]. This is because the residential neighbourhood remains the place for membership in religious and lay organizations, and schools [27]-[29]. Residents are usually more socially- and economically-similar inside a neighbourhood than they are city-wide [30]. Alternatively, cosmopolitan residents of older-urban neighbourhoods may have comparable neighbouring and spatial activities, and be satisfied with local socio-economic diversity and non-traditional lifestyles [31]. In sum, not 
only residents but also potential offenders may experience a neighbourhood differently near or far from a home. If they do this, then the neighbourhood's individual private properties, its area, and its adjacent area will each have their own potentially-independent attributes for which safeties should be measured [22] [32]-[34].

This study will therefore analyze residents' safeties of the attributes of their neighbourhood's individual private properties, area, adjacent area and exterior lighting. It will then proceed, as flowcharted in Figure 1, to compare residents' perceived less safe attributes of neighbourhoods having different ages of construction, and urban, suburban, or rural and small town locations. Relative safeties of exterior attributes are measured under the assumption most attributes will be safe in absolute terms [35]. Residents of Canadian neighbourhoods are presumed to feel safe rather than unsafe outside their homes both in daylight and darkness. They could feel this way even while residents of older-urban neighbourhoods may judge they have more unsafe attributes than those in newer and older suburban or rural and small town ones.

The consequent research objectives are to infer which attributes are less safe, and where they tend to be located, and then to propose planning methods for improving their safety. Our proposals will be about altering attributes of properties and streets by means of physical planning and environmental design for better natural surveillance, territoriality, activity support, and access control in an existing neighbourhood. As already explained in two studies [36] [37], if planners know what residents perceive as important in creating safe residential environments, then they may assist with straightforward and cost-effective alterations without relying on

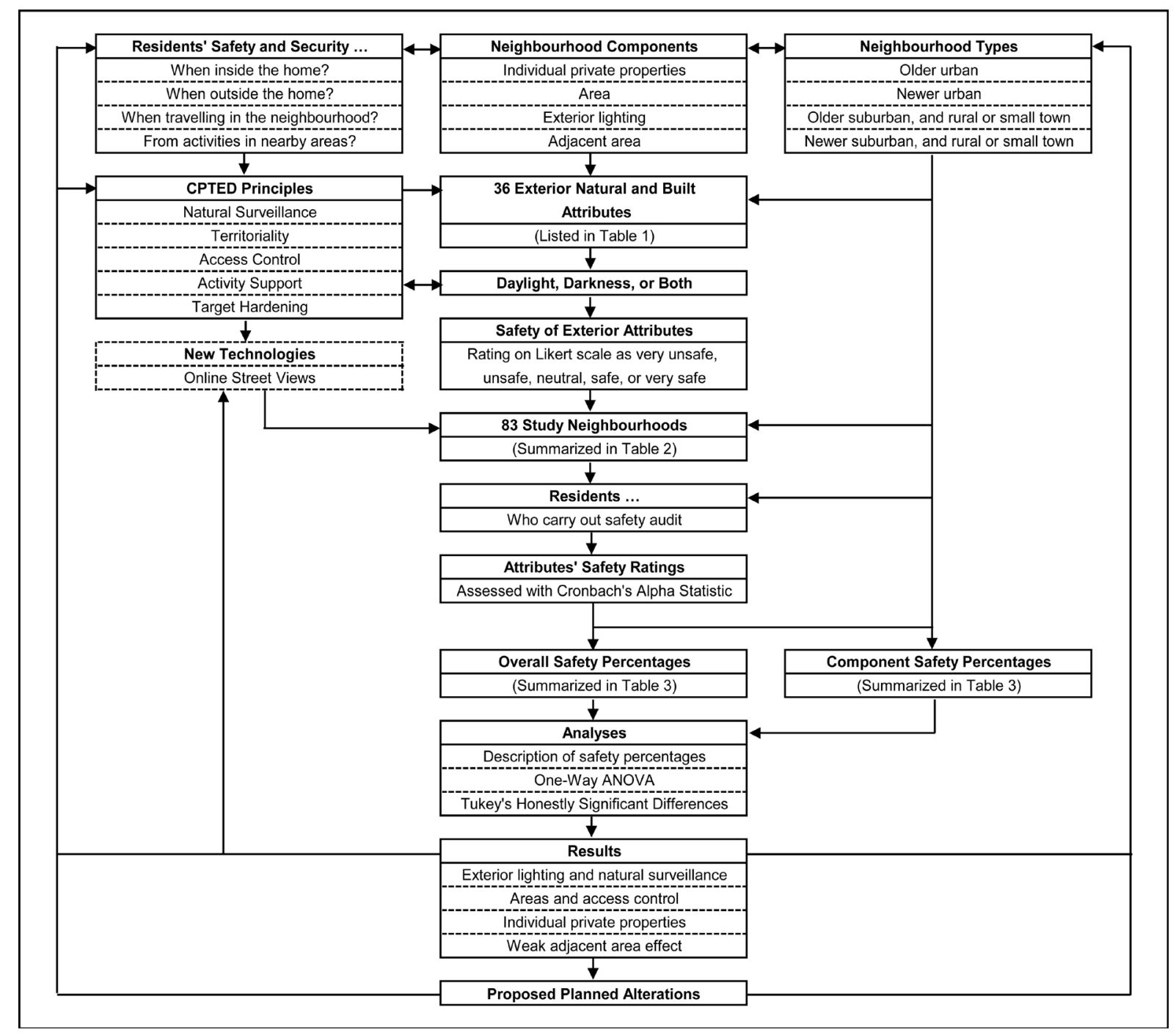

Figure 1. Flowchart of the study. 
experts' opinions of what those alterations should be [38] [39].

This study's measurement of unsafe attributes is further inspired by a question about the potential applicability of new technologies for CPTED [5], such as remote observation of local conditions creating personal-or property-security issues while browsing online street views of properties and streets

(http://en.wikipedia.org/wiki/Google_Street_View\#North_America). Street view panoramas of this study's neighbourhoods are composed of stitched-together photographs, taken from public property (streets), on bright and clear summery days. These simulate conditions under which safety audits were conducted in daylight (e.g., from http://web2.uwindsor.ca/courses/sociology/phipps/courses/np/safetyauditmaps.html). Street view panoramas may thus only be useful if exterior attributes are unsafe in daylight, or the same ones are unsafe in daylight and darkness. Hence, this study's objectives are to measure which attributes are unsafe, and where and when.

In the final analysis, this study does not test whether safer forms of residential neighbourhoods have prevented situational crime by increasing rational offenders' efforts for crime, increasing their risks of crime detection, reducing their rewards from crime or provocations for it, and/or removing their excuses for it [40]-[43]. Rarely-occurring criminal offences might not be observed frequently enough for correlating with attributes of residential environments [33] [44]. For example, the authors of another study could only measure a few statistically-significant relationships between types of crime and environmental attributes of car parking and through-movement/connectivity [1]. This was because $86 \%$ of studied properties across twelve sites experienced no reported crime during a three year analysis period, while $11 \%$ experienced one crime.

In any case, alterations to property and street attributes may not prevent crime and disorder incidents [45]-[47]. They may nonetheless mitigate residents' disproportionate fear of crime and disorder, and/or translate into more awareness of risks in not only older-urban neighbourhoods but also newer or rural ones where victimization rates are lower [35] [48]-[50]. Implementation of CPTED components should shift guardianship of neighbourhood properties and streets away from the needs and desires of strangers [42]. Such implementation may do this, while possibly not preventing local crime and disorder perpetrated by residents themselves, their visitors, or anybody under the influence of alcohol or drugs [51]-[53].

\section{Exterior Attributes of Home and Neighbourhood}

This study's focus of attention is upon a subset of attributes of a neighbourhood's individual private properties, area, adjacent area and exterior lighting that may serve either to protect residents from crime and disorder, or to expose them while they are outside the home [54]. A home's attributes are frequently theorized as generating flows of psychological, social, economic and environmental services for residents [55]-[58].

Each experienced home attribute, according to this theory, creates a subjective value or utility for residents based upon their residential preferences and constraints [59] [60]. An attribute's contribution towards (dis-) satisfaction with living in the current home is thus only predictable if knowing a resident's valuation of this attribute [61]. Relevantly for this study, some attributes of the home may have special functions in making residents feel personally-safe and secure about their property. Modern CPTED principles are for home and neighbourhood attributes to be safe or unsafe depending upon whether they do or do not help natural surveillance, territoriality, access control, activity support and target hardening [33]. Hence, similarly to other residential attributes, each CPTED attribute's presence or absence will have a personalized consequence for a resident in terms of his or her perceived safety of living in the home and neighbourhood.

Note that no attributes in this study represented the fifth CPTED component of target hardening, where this might include interior installations of dead bolt locks, solid core doors, lockable windows and related hardware components, or security alarm systems etc. Observation of homes' interior conditions from the outside is both intrusive and impracticable; and in any case, non-residents have little authority over physical alterations inside the home (cf. [62]).

Thirty-six surveyed exterior attributes of homes and neighbourhoods representing the four CPTED components are listed in Table 1 (cf. [63]). Natural surveillance capabilities outside the home are represented by 11 attributes of a neighbourhood's individual private properties and area in daylight and darkness, and under the exterior lighting in darkness. Eight attributes represent territorialities in the area and around the individual private properties in daylight and darkness. Beyond the home, seven attributes are for access controls in the area and around the individual private properties in daylight and darkness. Farther away, four of ten attributes represent the activity supports in the area and of the individual private properties for residential activities in day 
Table 1. Study neighbourhood attributes.

\begin{tabular}{|c|c|c|c|}
\hline $\begin{array}{l}\text { CPTED } \\
\text { Principle }\end{array}$ & $\begin{array}{l}\text { Study Neighbourhood } \\
\text { Component }\end{array}$ & Attribute & (Survey Q. No.) \\
\hline \multirow{11}{*}{$\begin{array}{l}\text { Natural } \\
\text { Surveillance }\end{array}$} & \multirow[t]{3}{*}{ Area } & Topography’s views and sightlines. & $(1.3)$ \\
\hline & & Utility corridors' locations and appearances. & $(1.11)$ \\
\hline & & Vegetation and foliage trimmed and neat. & $(1.12)$ \\
\hline & \multirow{6}{*}{$\begin{array}{l}\text { Exterior } \\
\text { Lighting }\end{array}$} & Average illumination bright enough. & $(4.6)$ \\
\hline & & Illuminates pedestrian public and/or private walkways. & $(4.4)$ \\
\hline & & Municipal street- and/or park-lighting. & $(4.1)$ \\
\hline & & Municipal street-lighting vandalism or burnt-out bulbs. & $(4.2)$ \\
\hline & & Pockets of shadowing. & $(4.5)$ \\
\hline & & Private exterior lighting. & $(4.3)$ \\
\hline & \multirow{2}{*}{$\begin{array}{l}\text { Individual Private } \\
\text { Properties }\end{array}$} & Views and sightlines ${ }^{\dagger}$. & (2.5) \\
\hline & & Walkways or driveways. & $(2.12)$ \\
\hline \multirow[t]{8}{*}{ Territoriality } & \multirow[t]{2}{*}{ Area } & Centre or focal point. & $(1.6)$ \\
\hline & & Symbols, graffiti, or vandalism ${ }^{\dagger \neq}$. & (1.9) \\
\hline & \multirow{6}{*}{$\begin{array}{l}\text { Individual Private } \\
\text { Properties }\end{array}$} & Ancillary uses such as sheds and garages ${ }^{\ddagger \ddagger}$. & (2.6) \\
\hline & & Borders or fences visibly maintained ${ }^{\dagger \ddagger}$. & $(2.8)$ \\
\hline & & Residents’ vehicles parked off-street ${ }^{\ddagger}$. & (2.9) \\
\hline & & Safety signs such as neighbourhood watch, safewalk, or curfews. & $(2.11)$ \\
\hline & & Special safety problems for young children. & $(2.13)$ \\
\hline & & Symbols, graffiti, or vandalism ${ }^{\dagger \neq}$. & (2.3) \\
\hline \multirow{7}{*}{$\begin{array}{l}\text { Access } \\
\text { Control }\end{array}$} & \multirow[t]{5}{*}{ Area } & Mix of land uses including vacant lots ${ }^{\ddagger}$. & $(1.5)$ \\
\hline & & Not entrapping. & $(1.10)$ \\
\hline & & On-street parking. & $(1.13)$ \\
\hline & & Public pedestrian walkways' locations and conditions. & $(1.8)$ \\
\hline & & Street signs at corners or intersections are or are not visible from at least $20 \mathrm{~m}^{\dagger}$. & $(1.7)$ \\
\hline & \multirow{2}{*}{$\begin{array}{l}\text { Individual Private } \\
\text { Properties }\end{array}$} & Gaps and spaces between ${ }^{\dagger \neq}$. & $(2.7)$ \\
\hline & & House numbers or other signs that are visible from $10 \mathrm{~m}$. & $(2.10)$ \\
\hline \multirow{10}{*}{$\begin{array}{l}\text { Activity } \\
\text { Support }\end{array}$} & \multirow[t]{6}{*}{ Adjacent Area } & Access from people and traffic. & $(3.5)$ \\
\hline & & Compatible commercial and/or industrial activities. & $(3.2)$ \\
\hline & & Compatible recreational and/or open spaces. & $(3.3)$ \\
\hline & & Compatible residential activities ${ }^{\dagger}$. & $(3.1)$ \\
\hline & & Generate daytime traffic. & (3.4) \\
\hline & & People and traffic unnecessarily passing through. & (3.6) \\
\hline & \multirow[t]{3}{*}{ Area } & Design and layout promotes or encourages activities. & $(1.2)$ \\
\hline & & Layout and appearance ${ }^{* \ddagger}$. & $(1.1)$ \\
\hline & & Planned streets and roadways. & $(1.4)$ \\
\hline & Individual Private Properties & Physical upkeep and maintenance ${ }^{\dagger \ddagger}$. & $(2.2)$ \\
\hline
\end{tabular}

${ }^{\dagger}$ Honestly significant difference between mean ratings in daylight at $\rho \leq 0.05$; ${ }^{\ddagger}$ Honestly significant difference between mean ratings in darkness at $\rho \leq$ 0.05 .

light and darkness; and the remainder, the adjacent area's possibly incompatible effects on this local activity support in daylight. An adjacent area may be relatively near from a resident's perspective if his or her neighbourhood only includes the equivalent of several city-blocks on several streets. Note finally these surveyed exterior attributes of low-density Canadian residential neighbourhoods are similar to those in another recent study [33] — while they are less representative of higher-density environments that originally inspired the formulation of modern CPTED theory [64]-[66].

\subsection{Natural Surveillance Attributes}

The CPTED principle of natural surveillance is that a neighbourhood's public sidewalks, streets, parks and 
buildings, and its private properties, should be safer for everybody's outside activities where more residents have watchful eyes over those areas and properties-and some residents hopefully would be willing to intervene during the commission of a crime [67] [68]. Residents' surveillance from individual private properties should therefore be enabled by good views and sightlines of walkways, driveways and building entries (Attributes surveyed in questions numbered 2.5 and 2.12 in Table 1). Conversely, surveillance may be constrained by the area's topography, vegetation and foliage, and especially in utility corridors located in back alleys (Qs 1.3, 1.11 and 1.12). Either way, natural surveillance during darkness should be improved with bright municipal or private street-lighting, or both (Qs 4.1, 4.3 and 4.6) [65] [69]. Exterior lighting however needs to be functioning and illuminating pedestrian public and/or private walkways, without pockets of shadowing (Qs 4.2, 4.4 and 4.5) [70] [71].

\subsection{Territoriality Attributes}

Territoriality refers to residents being more likely to maintain and safeguard their own private properties and useable public areas if they have a sense of ownership of those properties and belonging in those areas [72]. Conscious resident action may especially be motivated for creating this physical and/or symbolic territory for children who could be exposed to special safety problems outside the home (Q 2.13). Signs on private properties about participation in crime-minimizing strategies may publicise not only the habitual presence of adult residents but also their membership in a community monitoring the area (Q 2.11) [73].

Private properties nearest the home should appear demarcated with visibly-maintained boundaries and fences, designated off-street parking space, and well-maintained ancillary uses such as sheds and garages (Qs 2.6, 2.8 and 2.9). Symbols, graffiti or vandalism should not be tolerated on individual properties, or farther away in public areas where residents have social and physical control over space (Qs 1.9 and 2.3) [73] [74]. Even if modern residents feel less collective territoriality over semi-private yard-spaces and public sidewalks, streets and parks [22], an exception may be the inclusion in one's local territory of a farther-away focal point, such as school or community centre (Q 1.6) [75]. Note in general that attributes representing territoriality in these low-density Canadian residential neighbourhoods were not in conflict with those representing natural surveillance, such as if obscuring lines of sight, as has been queried in two studies [65] [76].

\subsection{Access Control Attributes}

Access control refers to the promotion of personal and property safety within a neighbourhood if entry into its public spaces, and passage through them, is dissuaded for individuals without a purpose for being there. Even if residents are more concerned about the safety of their own private property, they nevertheless will travel through their area to their home's location as the origin and destination of most trips for household members, as well as the destination for admissible visitors in delivery or emergency vehicles. Travel should thus be safer with sidewalks and unobstructed gaps between individual private properties; and more legible plans and mixes of land uses (Qs 1.5, 1.8, 1.10 and 2.7) [35] [77]. Correspondingly, visitors' private access should be assisted with visible street signs at corners or intersections in the area; house-numbers or other signs on individual private properties; and convenient on-street parking in the area (Qs 1.7, 1.13 and 2.10).

\subsection{Activity Support Attributes}

A home provides shelter from nature and space for household members, and so, personal activities inside the home should be supported by a visibly well-maintained house (Q 2.2). Property owners should be motivated to alter less safe attributes if this adds to their current or future subjective property-value, as this is the typical reason for home maintenance and upkeep [78] [79]. The constraints are owners may lack resources for maintaining the home and yard, whereas renters may derive too little personal benefit from doing it [80] [81].

Residents' activities farther away from the home, ranging from adults' socialising to children's playing, should be supported by planned road designs and layouts (Qs 1.1, 1.2 and 1.4) [82]. Their activities may however be disrupted even in daylight by people and traffic accessing or passing through their streets, especially from the adjacent area's incompatible residential or commercial/industrial land uses, or recreational/open spaces (Qs 3.1 to 3.6) [36] [51]. 


\subsection{Older-Urban Residential Neighbourhoods}

In review, therefore, modern CPTED principles have been applied in the foregoing four subsections to define attributes of built and natural environments in residential neighbourhoods that may reinforce residents' feelings of safety outside the home for themselves and their property - and other attributes that may weaken their feelings even if the opportunities provided by those conditions for local crime and disorder have not translated in more actual offences [83]. An area's safety is defined by five attributes for access control, three attributes each for activity support and natural surveillance, and two for territoriality. Individual private properties: six territorialities, two surveillances, two access controls, and one activity support. Adjacent area: six activity supports. And exterior lighting: six surveillances.

In reality, weaker feelings of safety may especially correlate with residents' experiencing or witnessing more crime and disorder in older-urban neighbourhoods than elsewhere [84]-[89]. Feelings of safety in older-urban neighbourhoods may be influenced by not only environmental differences but also higher concentrations of members of at-risk sub-populations with age, income and lifestyle constraints, and propensities for moving in and out of a neighbourhood [90]-[93].

Canadian older-urban neighbourhoods surely have distinctive residential environments. For example, their housing is now almost 100 years-old, even if it was rehabilitated during the 1974-1982 period with funds from the federal government with provincial and municipal contributions [94]. Routine maintenance and upkeep may have lagged since then, while their natural environments have matured, so that daytime seediness may appear unsafe in darkness [69].

In addition, older-urban neighbourhoods—and, now, new intensified redevelopments of them-tend to have higher density housing and more mixed land uses with less spacing between them than in newer suburbs, rural areas or small towns [95] [96]. Thus, natural surveillance may be obscured even where older-urban homes are single-detached houses, duplexes, townhouses and/or low-rise apartment buildings [97]. Frequently-narrower older residential streets may also aggravate congestion from inadequate off-street parking; while rear-access alleyways compensating for this inadequacy have uncontrolled and unmonitored entries and exits [81].

Older residential maintenance and upkeep may further be stifled if core locations are under pressure for redevelopment for higher density residential or commercial projects, or transition to adaptive non-residential uses [78] [80]. Older-urban neighbourhoods are thus more likely than elsewhere to have non-residential land uses in the form of private and public facilities for patrons during the evening, including those that may be crime generating or crime attracting [98] [99]. Some facilities will aid residents, such as job centres or missions; while others also catering to visitors range from small taverns up to large urban casinos [100]. Visitors' activities may be un-neighbourly outside those facilities [22] [101] [102].

Note that this study's focus upon measuring and altering unsafe attributes of built and natural environments emphasizes one type of planning for better personal and property safety in residential neighbourhoods [66] [75]. A second type of planning is to prohibit clusters of non-residential land uses if these promote criminal or disorderly spatial activities of residents or visitors [102]. A third is to promote cohesive involvement in neighbourhood life and activity of all residents including those with lifestyle, age and income constraints, such as recent immigrants, the elderly, and unemployed [103]-[105]. In reality, all three types of plans may be needed for older-urban neighbourhoods [81] [99]_and, possibly soon, older suburban neighbourhoods as in the USA [106] [107].

\section{Methodology}

\subsection{Attribute Safeties and Overall Safety Percentages}

Perceived safeties outside the home were measured in this study for a sample of 83 residents who rated the safeties of 36 exterior attributes of their own neighbourhoods' areas, individual private properties, adjacent area, and exterior lighting. Each attribute was operationally rated along a five-point Likert scale as either very unsafe, unsafe, neutral, safe, or very safe in daylight (scored from 1 to 5), darkness (scored from 6 to 10), or both—unless it was absent in a study neighbourhood. Note these scales directly measured an opinion of each attribute's safety, so as to avoid confusion, for example, about the meaning of disagreeing with a statement about an attribute's safety. Ratings of a study neighbourhood assume it has relatively uniform exterior attributes and safeties, thereby avoiding repetitious surveying of individual private properties, such as has been done in two studies [1] [2]. 
Thirteen attributes of the area were subsequently rated for safety in daylight, as well as 11 attributes of individual private properties in daylight, and six of the adjacent area in daylight—and correspondingly in darkness, 13 attributes of the area, 11 of the individual private properties, and six of the exterior lighting. Subsequent ratings of attributes within each of these six components were summed without differential weighting after rescaling around the neutral midpoints. An intuitive $(-100) \%$ to $100 \%$ percentage for each component's overall safety was then produced by dividing its rating subtotal by its possible maximum or minimum not-absent ratings also rescaled around the neutral midpoints. Component percentages were then averaged for an overall measure of a study neighbourhood's safety in daylight or darkness. Overall safety percentages therefore ranged from $(-100) \%$ if a study neighbourhood had uniformly very unsafe ratings for attributes of its area, individual private properties, and adjacent area or exterior lighting - to $100 \%$ if it had uniformly very safe ratings.

Note the summations of observed ratings of attributes for each of six components of study neighbourhoods were justified because they were reliably measuring the same feeling of safety in the neighbourhood, according to Cronbach's Alpha statistic. With the exception of the Alpha statistic of 0.71 for safety of the adjacent area, the Alpha statistics for five remaining components ranged most satisfactorily between 0.86 and 0.925 on a zero to unity scale. The adjacent area component's somewhat lower Alpha statistic may have been induced by its inclusion of disparate attributes of adjacent land use and traffic in order to represent a diversity of adjacent areas.

\subsection{Study Neighbourhoods}

As already mentioned, 83 residents rated the safeties of properties and streets in their own neighbourhoods. Each study neighbourhood is a neighbourhood or part of a larger one from a resident's perspective, typically including the equivalent of several city-blocks on several streets. Each study neighbourhood is located around a different surveyor-resident's temporary or permanent home in either Windsor-Essex County, Ontario (68 of them); South-Western Ontario (8); or Greater Toronto Area (7). Surveyors were undergraduate students enrolled in an upper-year neighbourhood planning course, and they included both young men (47\%) and young women (53\%). They had selected themselves for enrollment in this elective course, and so, study neighbourhoods surrounded randomly-located homes. Students received training during the course for conducting the safety audit in their neighbourhood.

None of their subsequently-calculated safety percentages were statistically different by gender (cf. [108]). Male and female surveyors therefore had not only similar types of study neighbourhoods $(\rho=0.47)$. They also had similar average overall safeties for the areas of these study neighbourhoods, and their individual private properties, adjacent areas, and exterior lighting during daylight or darkness or both (all $\rho>0.14$ ). In sum, trained young adults may not be special neighbourhood residents for this surveying. Similarly, another study did not find statistically-different perceptions of safety of neighbourhoods by residents' gender, education, income, age and race [36].

Each study neighbourhood was classified after-the-fact as either older urban (OU; 21 of them); newer urban (NU; 18); older suburban, rural or small town (OSRST; 14); or newer suburban, rural or small town (NSRST; 30). This classification into subsamples was based upon a combination of an age of construction in the "1920s", "1950s or 1960s", or "1970s or more recent"; and an "urban", "suburban", or "rural or small town" location in a current or former municipality (Table 2). This combination of two characteristics basically subsumes three additional recorded characteristics of types of dwelling units, tenure classes and types of residents.

For example, $93 \%$ of OSRSTs, and $80 \%$ of NSRSTs had exclusively single-detached houses. Lower proportions of OUs and NUs had those types of homes (29\% and 22\%, respectively), as they additionally had single-detached houses mixed with duplexes (71\% and 33\%, respectively)—and with townhouses (28\%) and apartment buildings (17\%) in NUs. Further correlating with these combinations, residents in OSRSTs and NSRSTs were predominantly owner-occupiers (79\% and $83 \%$, respectively), and families with or without children (93\% and $87 \%)$; whereas unattached individuals (71\% and $11 \%)$, or a mix of them and families (24\% and $78 \%$ ), lived in OUs and NUs.

As this study's objectives are measuring and comparing not only safe and unsafe residential attributes, but also their locations, the classification of study neighbourhoods into four subsamples is the factor variable in one-way analyses of variance (ANOVA), with the overall safety percentages and attribute ratings as dependent variables. Study neighbourhoods were defined by random home locations of surveyor-residents. Statistically-significant differences between subsamples' mean percentages or ratings are identified with Tukey's honestly 
Table 2. Types of study neighbourhoods.

\begin{tabular}{|c|c|c|c|c|c|c|c|c|c|c|}
\hline \multirow[b]{3}{*}{ Characteristic } & \multicolumn{10}{|c|}{ Study Neighbourhood Classification } \\
\hline & & \multicolumn{2}{|c|}{ Older Urban } & \multicolumn{2}{|c|}{ Newer Urban } & \multicolumn{2}{|c|}{$\begin{array}{l}\text { Older Suburban, } \\
\text { Rural or Small } \\
\text { Town }\end{array}$} & \multicolumn{2}{|c|}{$\begin{array}{c}\text { Newer Suburban, } \\
\text { Rural or Small } \\
\text { Town }\end{array}$} & \multirow{2}{*}{$\begin{array}{l}\text { Total } \\
\text { Count }\end{array}$} \\
\hline & Characteristic Levels & Count & Percent & Count & Percent & Count & Percent & Count & Percent & \\
\hline \multirow[t]{3}{*}{ Location } & Centre & 21 & $100 \%$ & 18 & $100 \%$ & 0 & $0 \%$ & 0 & $0 \%$ & 39 \\
\hline & Suburban & 0 & $0 \%$ & 0 & $0 \%$ & 11 & $79 \%$ & 26 & $87 \%$ & 37 \\
\hline & Rural or Small Town & 0 & $0 \%$ & 0 & $0 \%$ & 3 & $21 \%$ & 4 & $13 \%$ & 7 \\
\hline \multirow{3}{*}{$\begin{array}{c}\text { Age of } \\
\text { Construction }\end{array}$} & 1920s & 21 & $100 \%$ & 0 & $0 \%$ & 1 & $7 \%$ & 0 & $0 \%$ & 22 \\
\hline & 1950s or 1960 s & 0 & $0 \%$ & 12 & $67 \%$ & 13 & $93 \%$ & 0 & $0 \%$ & 25 \\
\hline & 1970s or More Recent & 0 & $0 \%$ & 6 & $33 \%$ & 0 & $0 \%$ & 30 & $100 \%$ & 36 \\
\hline \multirow{4}{*}{$\begin{array}{l}\text { Types of } \\
\text { Dwelling } \\
\text { Units }\end{array}$} & Single-Detached Houses & 6 & $29 \%$ & 4 & $22 \%$ & 13 & $93 \%$ & 24 & $80 \%$ & 47 \\
\hline & $\begin{array}{c}\text { Duplexes and Single-Detached } \\
\text { Houses }\end{array}$ & 15 & $71 \%$ & 6 & $33 \%$ & 0 & $0 \%$ & 2 & $7 \%$ & 23 \\
\hline & Townhouses & 0 & $0 \%$ & 5 & $28 \%$ & 1 & $7 \%$ & 3 & $10 \%$ & 9 \\
\hline & Apartment Buildings & 0 & $0 \%$ & 3 & $17 \%$ & 0 & $0 \%$ & 1 & $3 \%$ & 4 \\
\hline \multirow{3}{*}{$\begin{array}{l}\text { Tenure Class } \\
\text { of Residents }\end{array}$} & Owners & 1 & $5 \%$ & 1 & $6 \%$ & 11 & $79 \%$ & 25 & $83 \%$ & 38 \\
\hline & Renters & 14 & $67 \%$ & 9 & $50 \%$ & 1 & $7 \%$ & 0 & $0 \%$ & 24 \\
\hline & Owners and Renters & 6 & $29 \%$ & 8 & $44 \%$ & 2 & $14 \%$ & 5 & $17 \%$ & 21 \\
\hline \multirow[t]{3}{*}{$\begin{array}{l}\text { Types of } \\
\text { Residents }\end{array}$} & $\begin{array}{l}\text { Families With or Without } \\
\text { Children }\end{array}$ & 1 & $5 \%$ & 2 & $11 \%$ & 13 & $93 \%$ & 26 & $87 \%$ & 42 \\
\hline & Unattached Individuals & 15 & $71 \%$ & 2 & $11 \%$ & 0 & $0 \%$ & 0 & $0 \%$ & 17 \\
\hline & $\begin{array}{l}\text { Mixture of Families and } \\
\text { Individuals }\end{array}$ & 5 & $24 \%$ & 14 & $78 \%$ & 1 & $7 \%$ & 4 & $13 \%$ & 24 \\
\hline
\end{tabular}

significant difference (HSD) post-hoc tests. Note that a one-way ANOVA with a statistically-significant overall F statistic (at significance level $\rho<0.05$ ) will have at least one statistically-significant HSD between pairs of subsamples' mean safety percentages or ratings (also at significance level $\rho<0.05$ ). An HSD's significance level may therefore be reported in the text without the overall F-statistic.

\section{Analysed Safeties of Neighbourhoods and Their Attributes}

The 83 audited study neighbourhoods were overall moderately- to quite-safe in daylight, and somewhat less safe in darkness, especially in the case of older-urban (OU) neighbourhoods. On the percentage scale from $(-100) \%$ for uniformly very unsafe ratings, to $100 \%$ for uniformly very safe ratings, significantly-different average overall safeties in daylight ranged from $19 \%$ in OUs, $24 \%$ in newer-urban (NU) ones, up to approximately equal at $46 \%$ and $45 \%$ in older- and newer-suburban, rural or small town (OSRST and NSRST) ones (F = 6.8, $\rho=0.000$; Table 3). In addition to having similar between-neighbourhood differences in darkness ( $\mathrm{F}=4.4, \rho=0.006$ ), the study neighbourhoods averaged significantly less safe in darkness, at $4 \%$ in NUs, $20 \%$ in OSRSTs and $21 \%$ in NSRSTs, and as mentioned, unsafe at $(-8) \%$ in OUs (Paired samples overall $\mathrm{T}=13.5, \rho<0.001$ ). Lower overall safeties in darkness than in daylight were particularly due to the uniformly-low safeties of the exterior lighting in darkness (with an average safety of $2 \%$ ), and the unevenly-lower ones of the area in darkness (with an average $9 \%)$.

\subsection{Safeties of Exterior Lighting}

Uniformly-low mean safety percentages for exterior lighting in darkness ranged from (-9)\% for OUs, to $(-1) \%$ for NUs, and to $10 \%$ and $7 \%$ for OSRSTs and NSRSTs, respectively ( $\mathrm{F}=0.8, \rho=0.5$ ). Each type of average study neighbourhood would thus have had poorly lit real estate and streets in darkness. Overall safeties of lighting within subsamples were depressed by lower ratings for private and/or municipal street-lighting's not illuminating pedestrian public and/or private walkways, and in pockets of shadowing. Overall safeties were however not associated with private porch-lighting in one type of neighbourhood, and municipal street-lighting in another. 
Table 3. Study neighbourhoods’ summary safety percentages.

\begin{tabular}{|c|c|c|c|c|c|c|c|c|c|}
\hline Component & $\begin{array}{l}\text { Number of } \\
\text { Attributes }\end{array}$ & Period & $\begin{array}{c}\text { Overall F } \\
\text { Statistic }\end{array}$ & $\begin{array}{l}\text { Overall F } \\
\text { Sig. Level }\end{array}$ & $\begin{array}{c}\mu \\
\text { OU\% }\end{array}$ & $\begin{array}{c}\mu \\
\text { NU\% }\end{array}$ & $\begin{array}{c}\mu \\
\text { OSRST\% }\end{array}$ & $\begin{array}{c}\mu \\
\text { NSRST\% }\end{array}$ & $\begin{array}{c}\mu \\
\text { Overall\% }\end{array}$ \\
\hline Adjacent Area & 6 & Daylight & 3.4 & 0.023 & $20 \%$ & $12 \%$ & $45 \%^{\ddagger}$ & $30 \%$ & $26 \%$ \\
\hline \multirow[t]{2}{*}{ Area } & 13 & Daylight & 3.7 & 0.015 & $22 \%$ & $32 \%$ & $47 \%^{\dagger}$ & $45 \%^{\dagger}$ & $37 \%$ \\
\hline & 13 & Darkness & 3.6 & 0.017 & $(-8) \%$ & $6 \%$ & $20 \%^{\dagger}$ & $17 \%^{\dagger}$ & $9 \%$ \\
\hline Exterior Lighting & 6 & Darkness & 0.8 & 0.497 & $(-9) \%$ & $(-1) \%$ & $10 \%$ & $7 \%$ & $2 \%$ \\
\hline \multirow[t]{2}{*}{ Individual Private Properties } & 11 & Daylight & 10.1 & 0.000 & $15 \%$ & $21 \%$ & $47 \%^{\dagger}$ & $54 \%{ }^{\dagger+}$ & $36 \%$ \\
\hline & 11 & Darkness & 7.5 & 0.000 & $(-6) \%$ & $5 \%$ & $27 \%^{\dagger}$ & $35 \%{ }^{\dagger \neq}$ & $16 \%$ \\
\hline \multirow[t]{2}{*}{ Access Control } & 7 & Daylight & 4.2 & 0.009 & $19 \%$ & $23 \%$ & $47 \%^{\dagger}$ & $41 \%^{\dagger}$ & $33 \%$ \\
\hline & 7 & Darkness & 2.6 & 0.058 & $(-14) \%$ & $(-1) \%$ & $10 \%$ & $10 \%$ & $1 \%$ \\
\hline \multirow[t]{2}{*}{ Activity Support } & 10 & Daylight & 5.3 & 0.002 & $21 \%$ & $22 \%$ & $49 \%{ }^{\dagger \neq}$ & $42 \%^{\dagger}$ & $34 \%$ \\
\hline & 4 & Darkness & 8.0 & 0.000 & $(-11) \%$ & $10 \%$ & $29 \%^{\dagger}$ & $32 \%^{\dagger}$ & $16 \%$ \\
\hline \multirow[t]{2}{*}{ Surveillance } & 5 & Daylight & 3.3 & 0.026 & $20 \%$ & $30 \%$ & $41 \%$ & $45 \%^{\dagger}$ & $35 \%$ \\
\hline & 11 & Darkness & 1.6 & 0.206 & $(-7) \%$ & $1 \%$ & $15 \%$ & $13 \%$ & $6 \%$ \\
\hline \multirow[t]{2}{*}{ Territoriality } & 8 & Daylight & 8.2 & 0.000 & $17 \%$ & $26 \%$ & $46 \%^{\dagger}$ & $54 \%{ }^{\dagger \neq}$ & $37 \%$ \\
\hline & 8 & Darkness & 8.0 & 0.000 & $1 \%$ & $13 \%$ & $35 \%^{\dagger}$ & $40 \%{ }^{\dagger \ddagger}$ & $23 \%$ \\
\hline \multirow[t]{2}{*}{ Overall } & 30 & Daylight & 6.8 & 0.000 & $19 \%$ & $24 \%$ & $46 \%^{\dagger}$ & $45 \%{ }^{\dagger \neq}$ & $34 \%$ \\
\hline & 30 & Darkness & 4.4 & 0.006 & $(-8) \%$ & $4 \%$ & $20 \%^{\dagger}$ & $21 \%^{\dagger}$ & $10 \%$ \\
\hline
\end{tabular}

${ }^{\dagger}$ Lower $\mu \mathrm{OU} \%$ at $\rho \leq 0.05$; ${ }^{\ddagger}$ Lower $\mu \mathrm{NU} \%$ at $\rho \leq 0.05$; ${ }^{*}$ Where $\mu \mathrm{OU} \%$ is the mean percentage safety of older-urban study neighbourhoods; and likewise for NU, newer-urban neighbourhoods; and OSRST and NSRST, older- and newer-suburban, rural and small town neighbourhoods.

\subsection{Exterior Lighting and Natural Surveillance}

Marginally-safe/unsafe exterior lighting further contributed to study neighbourhoods' poor overall natural surveillance in darkness (average safety of 6\%). In daylight, five remaining attributes of surveillance indicated improved potential for natural surveillance not only within each type of study neighbourhood but also between types as well (average safety of 35\%). Only one surveillance attribute had an honestly significant difference between study neighbourhoods' mean safety ratings; and this was the less safe views and sightlines on OU individual private properties in daylight than in NSRSTs $(\rho=0.007)$. Otherwise, each type of average study neighbourhood would have had neither safe nor unsafe natural surveillance with different areas’ topography, vegetation and foliage, in utility corridors, and on private walkways or driveways between individual private properties.

\subsection{Safeties of the Areas and Their Attributes}

With more variability than for exterior lighting, OU areas in darkness averaged unsafe (-8\%), compared with the safeness of NU areas (6\%), and the significantly higher safeness of OSRST (20\%) and NSRST (17\%) areas in darkness ( $\mathrm{F}=3.6, \rho=0.017)$. Even though OU areas were safer in daylight than in darkness (22\%); OSRSTs (47\%) and NSRSTs (45\%) had areas with significantly higher average safeties than them in daylight $(\mathrm{F}=3.7, \rho$ $=0.015)$. Meanwhile, NU areas had middling average safeties in daylight (32\%) and darkness (6\%), which were not statistically different from either those of OU areas, or those of OSRST or NSRST areas (all at $\rho>0.38$ ).

Different ratings of four of 13 attributes of an area in daylight or darkness caused consistent differences between average safeties of OU and NSRST areas, and the frequent differences between those of OU and OSRST areas (Table 1). In particular, older and urban areas had lower perceived support for appropriate activities and territoriality as possible liabilities of their older age and urban setting. This was because the layout and appearance of the area was relatively less safe as an activity-support attribute in OU areas than in NSRST areas in daylight and darkness (both at $\rho<0.005)$, and in OSRST areas in darkness $(\rho=0.037)$. Similarly, territoriality was less safe with symbols, graffiti or vandalism on public areas for residents in both OU and NU areas than in NSRST areas in darkness (both at $\rho<0.03$ ); while OU areas were also less safe than NSRST areas for those symbols etc. in daylight $(\rho=0.032)$. 


\subsection{Areas and Access Control}

In addition, an average OU area would have poorer access control in daylight and darkness than another type of average area might have. In darkness, the mix of land uses including vacant lots in OU areas was less safe than in OSRST areas $(\rho=0.008)$. In comparison with NSRST areas in daylight, OU areas had less safe access control without visible street signs at corners or intersections from at least $20 \mathrm{~m}(\rho=0.026)$. In general, relatively poor overall access control in the area in darkness (overall average safety of $1 \%$ ) was being produced by the conditions of these attributes, as well as neither safe nor unsafe locations and conditions of public pedestrian walkways, on-street parking, and potential entrapping in public areas. In other words, OU residents' safety concerns may have emanated not only from the older layout of properties and appearance of buildings, but also from those neighbourhoods' central locations and mixed housing types if attracting strangers who were indistinguishable from residents themselves.

\subsection{Safeties of the Individual Private Properties and Their Attributes}

Inferences of OUs' averaging less safe than NSRSTs and frequently OSRSTs—but as safe as NUs_-are further corroborated by the significantly-different average safety ratings of seven of 11 attributes of their individual private properties during daylight and/or darkness (Table 1). In particular, four attributes described the less safe up-keep or maintenance of OU and NU individual private properties from a territorial perspective.

For example, OU and NU individual properties were rated, on average, as having marginally safe ancillary properties, such as sheds and garages. Moreover, these ancillary properties were statistically-significantly less safe in both OUs and NUs than in NSRSTs in daylight (both at $\rho<0.002$ ) —and OUs also had less safe ones than in NSRSTs in darkness $(\rho=0.01)$. Similarly, the visible maintenance of borders or fences was safer in NSRSTs than in OUs or NUs in daylight (both at $\rho<0.012$ ), and in OUs in darkness $(\rho=0.001$ ). Two additional average differences were similar to those between the area's attributes. Both OU and NU individual private properties were less safe than those of NSRSTs in daylight and darkness: first, for territoriality due to symbols, graffiti or vandalism on them (all at $\rho<0.015$ ); and second, for access control due to gaps and spaces between them (all at $\rho<0.002$ ). Also from an activity support perspective, both OUs and NUs had individual private properties with less safe physical upkeep and maintenance than those of NSRSTs in daylight and darkness (all at $\rho<0.021$ ), and OSRSTs in daylight (both at $\rho<0.019$ ) —and for OU individual properties, lower safety than in OSRSTs in darkness $(\rho=0.001)$.

One final average difference for the individual private properties was the lower safety of residents' vehicles parked off-street in OUs than in OSRSTs in darkness $(\rho=0.024)$; and this was in addition to the aforementioned lower safety of views and sightlines in OUs than in NSRSTs in daylight $(\rho=0.007)$. Otherwise, individual private properties' safety for children, and safety signs or house-number signs or other signs on them were neither safe nor unsafe in each type of study neighbourhood in daylight and darkness; and their walkways and driveways did not have restricted surveillance in daylight or darkness.

\subsection{Safeties of Adjacent Areas and Their Attributes}

Last, average safeties of adjacent areas in daylight were relatively similar between subsamples, at $20 \%$ for OUs, $12 \%$ for NUs and $30 \%$ for NSRSTs - but at $45 \%$ for OSRSTs for an overall statistically-significant difference ( $\mathrm{F}=3.4, \rho=0.023$ ). This component's only attribute with significantly-different mean ratings between subsamples was the compatibility of the adjacent area's residential activities with those in a study neighbourhood, for which NUs were, on average, as safe as OUs but less safe than either OSRSTs or NSRSTs (both at $\rho<0.007$ ). Study neighbourhoods' varying overall safeties were therefore products of their own built and natural environments. Activity support issues were not caused by uncontrolled access of traffic and people from the adjacent area, except where newer-urban neighbourhoods had adjacent (presumably) higher-density housing.

\section{Conclusions}

This study began by utilizing modern CPTED principles for defining natural and human-made attributes of properties and streets in existing Canadian residential neighbourhoods that might make residents feel safe or unsafe outside their homes. The further theoretical assumption was for residents' evaluating each exterior attribute's presence or absence as reinforcing or weakening their perceived safety of living in the home and 
neighbourhood. Residents were therefore enlisted and trained for surveying the safeties of those attributes of properties and streets in their neighbourhoods. Each study neighbourhood was basically several city-blocks on several streets comprising a neighbourhood from the resident's perspective. Study neighbourhoods contained low-density homes located on grid and curvilinear streets-but with older- and newer-urban ones possibly having combinations of single-detached houses, duplexes, townhouses and/or low-rise apartment buildings; and those in suburbs, and rural areas or small towns having almost exclusively single-detached houses. These were types of residential neighbourhoods that heretofore had not been safety audited by the practitioner of this study's two authors.

A positive result from a practical point of view is that average study neighbourhoods had overall moderatelyto quite-safe exterior attributes in daylight. They were however somewhat less safe in darkness, particularly under marginally safe or unsafe exterior lighting from public (municipal) street-lights or private porch-lights. Poor exterior lighting in darkness would further compound limitations to natural surveillance on older-urban individual private properties, as these already had poorer views and sightlines in daylight than elsewhere. Poor natural surveillance due to insufficient street lighting resembled that in a completely different, much denser Korean residential environment, which had narrow and curved paths that connected continually and repeatedly [65]. In practice in Canada, residents leaving on more porch-lights may be the solution to poorly-lit residential neighbourhoods, under the assumption municipalities will not upgrade existing street-lights or install new ones.

A first inference is therefore that Canadian residents may have much different perceptions of the safeties of their properties and streets in darkness than they have in daylight. In addition to six exterior-lighting attributes, lower average safeties were observed in darkness, and not in daylight for the area's mix of land uses including vacant lots, and residents' parked cars off-street on the individual private properties.

A methodological implication of this first inference is that residents are able with our audit to survey residential attributes' safeties, but they should do this in darkness as well as in daylight, as recommended in several studies [1] [54] [69] [71]. A further implication is in ruling out the use of online Street View panoramas for replicating a comprehensive safety audit of a neighbourhood in darkness as well as in daylight. Even if inspection of daytime panoramas provided estimates of numbers of street-lights and/or porch-lights, their presence is not the safety issue but rather their illumination in darkness. That is, the effectiveness of exterior lights cannot be measured without seeing them lighted. Likewise, the safety of parked cars on the individual private properties cannot be assessed until drivers are home at night.

A second inference is about residents' properties and streets having different safeties depending upon their type of residential neighbourhood. In particular, twelve attributes of study neighbourhoods' areas, individual private properties, and adjacent areas were rated less safe in older and/or newer urban neighbourhoods in daylight and/or darkness, than they were in newer and/or older suburban, rural or small town neighbourhoods. Already mentioned have been the poorer views and sightlines between individual private properties, though this was the only surveillance attribute included in the twelve attributes with statistically-significant different mean safety ratings. Visibility of exterior activities especially in daylight was therefore unimpaired in all types of neighbourhoods, and this differs from two other studies [65] [68]. For example, natural surveillance in a much denser Korean residential environment was poor in spaces under and between buildings owing to blind spots [65].

In Canada, five attributes representing elements of territoriality had different safeties in types of study neighbourhoods. For example, older-urban individual private properties had less safely-maintained borders or fences in daylight and darkness, and less safely-parked vehicles off street in darkness, possibly because they either did not establish a resident's territoriality, or were confusing about it. This poor territoriality was also comparable to that in a Korean residential environment where cars were parked randomly on streets, and signage was inadequate [65]. In addition, Canadian residents of older-urban neighbourhoods felt territorially less safe than those in suburbs and rural areas or small towns, for example, where symbols, graffiti and vandalism were present in public areas or on individual private properties, and where ancillary uses such as sheds and garages appeared unsecured.

Planners complying with broken-windows theory should therefore advocate for the removal of symbols, graffiti and vandalism on private or public properties in order to enhance perceptions of territoriality in daylight and darkness [99] [109]. Similarly, the visibility of street signage at corners or intersections in older-urban areas could easily be improved for safer access control. However, better access control would be more difficult in older-urban neighbourhoods, and frequently newer-urban ones, if they had a less safe mix of land uses including 
vacant lots, and gaps and spaces between individual private properties. More than environmental alterations may be required if less safe access control is correlated with un-neighbourly routine activities of visitors, as hypothesized in another study [68]. More may be needed than the CCTV recommended by Korean planners for improving access control in much denser residential environments [65].

In short, direct involvement of residents should be required in lower density residential environments to alter less safe residential attributes, as long-recommended in other studies [4] [23] [36] [67]. Such attributes in our study neighbourhoods would include those two less safe access control attributes, as well as three activity support attributes of the layout and appearance of older-urban areas in daylight and darkness, the physical upkeep and maintenance of their individual private properties in daylight and darkness, and compatibility of the residential activities in the adjacent area. If residents are constrained from rehabilitating older housing and its surrounding land use, planners for their part should lobby to relax some constraints for owners by amending their municipality's rules about structural alterations in the form of building codes and zoning regulations; and/or discounting governmental financial "penalties" such as property tax reassessments [110]. Complementary site planning could include disallowing land-use intensification beyond a neighbourhood's physical design; and not permitting land-use conflicts caused by a disproportionate number of evening visitors, such as in a licensed establishment.

In conclusion, residents' perceptions of their own neighbourhoods should be more salient than those of strangers for surveying the attributes of properties and streets that make residents and visitors alike feel safe or unsafe. This study's surveyors have identified twelve natural and human-made residential attributes that they as residents perceive as unsafe, and so, planning methods have been proposed for making these attributes safer. The theoretical assumption has been for attributes to be safer if they create better natural surveillance, territoriality, access control, or activity support. This however is a theoretical relationship between four principles of modern CPTED theory and residents' perceptions of safety in their neighbourhood; and it has not been confirmed in conversations with surveyors, and so, this is an area of future research. A further area of future research is about residents' having personal or experiential characteristics predisposing them to perceive (un-)safe attributes in their own neighbourhood. On the one hand, the young trained male and female surveyors in this study had consistent perceptions of overall safeties of properties and streets in different types of existing Canadian residential neighbourhoods. On the other hand, however, this study has not considered the impracticalities of making residents safer in neighbourhoods where they disagree about attributes causing personal and property safety issues outside their homes.

\section{Acknowledgements}

The authors acknowledge the helpful comments of the Editor and anonymous referees for revising this article. The authors in addition thank their students for surveying the study neighbourhoods.

\section{References}

[1] Armitage, R., Monchuk, L. and Rogerson, M. (2011) It Looks Good, But What Is It Like to Live There? Exploring the Impact of Innovative Housing Design on Crime. European Journal on Criminal Policy and Research, 17, 29-54. http://dx.doi.org/10.1007/s10610-010-9133-8

[2] Marzbali, M.H., Abdullah, A., Razak, N.A. and Tilaki, M.J.M. (2012) Validating Crime Prevention through Environmental Design Construct through Checklist Using Structural Equation Modelling. International Journal of Law, Crime and Justice, 40, 82-99. http://dx.doi.org/10.1016/j.ijlcj.2011.08.005

[3] Clancey, G., Lee, M. and Fisher, D. (2012) Crime Prevention through Environmental Design (CPTED) and the New South Wales Crime Risk Assessment Guidelines. A Critical Review. Crime Prevention and Community Safety, 14, 1-15. http://dx.doi.org/10.1057/cpcs.2011.10

[4] Crowe, T.D. (2000) Crime Prevention through Environmental Design: Applications of Architectural Design and Space Management Concepts. 2nd Edition, Butterworth-Heinemann, Boston.

[5] Schneider, R.H. and Kitchen, Ted. (2007) Crime Prevention and the Built Environment. Routledge, London.

[6] Sorensen, S., Hayes, J.G. and Atlas, R. (2008) Understanding CPTED and Situational Crime Prevention. In: Atlas, R., Ed., 21st Century Security and CPTED: Designing for Critical Infrastructure Protection and Crime Prevention, CRC Press, Fort Lauderdale, 53-78.

[7] Horrobin, B.A. (2011) Crime Prevention through Environmental Design Assessment: Ford Ferndale Public Housing, 
5402-5526 Reginald Street, and 5506-5568 Lassaline Avenue, Windsor, Ontario. Windsor Police Service, Windsor. (Copy available from author).

[8] (2002) Crime Prevention Analysis Environmental Design Assessment: Glengarry-Marentette Neighbourhood, Windsor, Ontario. Windsor Police Service, Windsor. (Copy available from author).

[9] (2008) Ontario Municipal Board Hearing: High Security Lock Requirement for Condominium Conversion, Rivershore Tower, 3400 Erskine Street, Windsor, Ontario. Windsor Police Report to Ontario Municipal Board, Windsor. (Copy available from author).

[10] (2012) Crime Prevention through Environmental Design Assessment: Cherniak Manor, 120 Oak Street, Windsor, Ontario. Windsor Police Service, Windsor. (Copy available from author).

[11] (2005) Ontario Municipal Board Appeal: Proposed 3 Unit and 4 Unit Multiple Residential Dwellings, Indian Road and Donnelly Street, Windsor, Ontario. Windsor Police Service Report to the Ontario Municipal Board, Windsor. (Copy available from author).

[12] (2008) Crime Prevention through Environmental Design Assessment: 200 Block, Watson Avenue, Windsor, Ontario. Windsor Police Service, Windsor. (Copy available from author).

[13] Embleton, M. (1996) Community Safety Audits. Plan Canada, 36, 18-19.

[14] Saville, G. (1996) Situation Crime Prevention as Responsible Urban Design. Plan Canada, March/mars, 27-28.

[15] Thorpe, A. and Gamman, L. (2013) Walking with Park: Exploring the "Reframing" and Integration of CPTED Principles in Neighbourhood Regeneration in Seoul, South Korea. Crime Prevention and Community Safety, 15, $207-222$. http://dx.doi.org/10.1057/cpcs.2013.6

[16] Cozens, P., Hillier, D. and Prescott, G. (2001) Crime and the Design of Residential Property—Exploring the Perceptions of Planning Professionals, Burglars and Other Users: Part 2. Property Management, 19, 222-248. http://dx.doi.org/10.1108/EUM0000000005784

[17] Saville, G. (2009) SafeGrowth: Moving Forward in Neighbourhood Development. Built Environment, 35, 386-402. http://dx.doi.org/10.2148/benv.35.3.386

[18] Parnaby, P.F. (2006) Crime Prevention through Environmental Design: Discourses of Risk, Social Control, and a Neo-Liberal Context. Canadian Journal of Criminology and Criminal Justice, 48, 1-30. http://dx.doi.org/10.3138/cjccj.48.1.1

[19] Marzbali, M.H., Abdullah, A., Razak, N.A. and Tilaki, M.J.M. (2012) The Influence of Crime Prevention through Environmental Design on Victimisation and Fear of Crime. Journal of Environmental Psychology, 32, 79-88. http://dx.doi.org/10.1016/j.jenvp.2011.12.005

[20] Ham-Rowbottam, K.A., Gifford, R. and Shaw, K.T. (1999) Defensible Space Theory and the Police: Assessing the Vulnerability of Residences to Burglary. Journal of Environmental Psychology, 19, 117-129. http://dx.doi.org/10.1006/jevp.1998.0108

[21] Moran, R. and Dolphin, C. (1986) The Defensible Space Concept: Theoretical and Operational Explication. Environment and Behavior, 18, 396-416. http://dx.doi.org/10.1177/0013916586183006

[22] Reynald, D.M. and Elffers, H. (2009) The Future of Newman's Defensible Space Theory. Linking Defensible Space and the Routine Activities of Place. European Journal of Criminology, 6, 25-46. http://dx.doi.org/10.1177/1477370808098103

[23] Saville, G. and Cleveland, G. (2008) Second-Generation CPTED: The Rise and Fall of Opportunity Theory. In: Atlas, R., Ed., 21st Century Security and CPTED: Designing for Critical Infrastructure Protection and Crime Prevention, CRC Press, Fort Lauderdale, 79-90.

[24] Wellman, B. and Leighton, B. (1979) Networks, Neighborhoods and Communities: Approaches to the Study of the Community Question. Urban Affairs Review, 14, 363-390. http://dx.doi.org/10.1177/107808747901400305

[25] Dietz, R.D. (2002) The Estimation of Neighborhood Effects in the Social Sciences: An Interdisciplinary Approach. Social Science Research, 31, 539-575. http://dx.doi.org/10.1016/S0049-089X(02)00005-4

[26] Hipp, J. (2010) What Is the "Neighbourhood” in Neighbourhood Satisfaction? Comparing the Effects of Structural Characteristics Measured at the Micro-Neighbourhood and Tract Levels. Urban Studies, 47, 2517-2536. http://dx.doi.org/10.1177/0042098009359950

[27] Ahlbrandt, R.S. (1984) Neighborhoods, People, and Community. Plenum Press, New York.

[28] Brower, S. (1996) Good Neighborhoods: A Study of In-town and Suburban Residential Environments. Praeger, Westport.

[29] Farrell, S.J., Aubry, T. and Coulombe, D. (2004) Neighborhoods and Neighbors: Do They Contribute to Personal WellBeing? Journal of Community Psychology, 32, 9-25. http://dx.doi.org/10.1002/jcop.10082 
[30] McCulloch, A. (2003) An Examination of Social Capital and Social Disorganisation in Neighbourhoods in the British Household Panel Study. Social Science and Medicine, 56, 1425-1438. http://dx.doi.org/10.1016/S0277-9536(02)00139-9

[31] Caulfield, J. (1994) City Form and Everyday Life: Toronto’s Gentrification and Critical Social Practice. University of Toronto Press, Toronto.

[32] Brown, B.B. and Altman, I. (1983) Territoriality, Defensible Space and Residential Burglary: An Environmental Analysis. Journal of Environmental Psychology, 3, 203-220. http://dx.doi.org/10.1016/S0272-4944(83)80001-2

[33] Minnery, J.R. and Lim, B. (2005) Measuring Crime Prevention through Environmental Design. Journal of Architectural and Planning Research, 22, 330-341.

[34] Ratcliffe, J.H. (2003) Suburb Boundaries and Residential Burglars. Trends and Issues in Crime and Criminal Justice, Australian Institute of Criminology, 246, 1-6.

[35] Wekerle, G.R. and Whitzman, C. (1995) Safe Cities: Guidelines for Planning, Design, and Management. Van Nostrand Reinhold, New York.

[36] Grohe, B. (2011) Measuring Residents’ Perceptions of Defensible Space Compared to Incidence of Crime. Risk Management, 13, 43-61. http://dx.doi.org/10.1057/rm.2011.1

[37] Ziegler, E.H. (2007) American Cities, Urban Planning, and Place-Based Crime Prevention. The Urban Lawyer, 39, 859-875.

[38] Clancey, G. (2011) Crime Risk Assessments in New South Wales. European Journal on Criminal Policy and Research, 17, 55-67. http://dx.doi.org/10.1007/s10610-010-9134-7

[39] Parnaby, P. (2007) Crime Prevention through Environmental Design: Financial Hardship, the Dynamics of Power, and the Prospects of Governance. Crime, Law and Social Change, 48, 73-85. http://dx.doi.org/10.1007/s10611-007-9077-1

[40] Cornish, D.B. and Clarke, R.V. (2003) Opportunities, Precipitators and Criminal Decisions: A Reply to Wortley’s Critique of Situational Crime Prevention. In: Smith, M.J. and Cornish, D.B., Eds., Theory for Practice in Situational Crime Prevention, Crime Prevention Studies, Vol. 16, Criminal Justice Press, Monsey, 111-124.

[41] Robinson, M.B. (1996) The Theoretical Development of “CPTED”: 25 Years of Responses to C. Ray Jeffery. In: Laufer, W. and Adler, F., Eds., Advances in Criminological Theory, Vol. 8, Transaction Publishers, New Brunswick, 427-462.

[42] Robinson, M.B. (2010) Crime Prevention through Environmental Design (CPTED) and Related Approaches in the United States. Community Safety and Environmental Design, 1, 11-23.

[43] Shaftoe, H. (2004) Crime Prevention: Facts, Fallacies and the Future. Palgrave MacMillan, Hampshire.

[44] Taylor, R.B., Gottfredson, S.D. and Brower, S. (1980) The Defensibility of Defensible Space: A Critical Review and a Synthetic Framework for Future Research. In: Hirschi, T. and Gottfredson, M., Eds., Understanding Crime: Current Theory and Research. Sage Research Progress Series in Criminology, Vol. 18, Sage, Beverly Hills, 53-71.

[45] Casteel, C. and Peek-Asa, C. (2000) Effectiveness of Crime Prevention through Environmental Design (CPTED) in Reducing Robberies. American Journal of Preventive Medicine, 18, 99-115.

[46] Cozens, P.M., Saville, G. and Hillier, D. (2005) Crime Prevention through Environmental Design (CPTED): A Review and Modern Bibliography. Property Management, 23, 328-356. http://dx.doi.org/10.1108/02637470510631483

[47] Taylor, R.B. (2002) Crime Prevention through Environmental Design (CPTED): Yes, No, Maybe, Unknowable, and All of the Above. In: Bechtel, R.B. and Churchman, A., Eds., Handbook of Environmental Psychology, John Wiley, New York, 413-426.

[48] Basolo, V. and Strong, D. (2002) Understanding the Neighborhood: From Residents' Perceptions and Needs to Action. Housing Policy Debate, 13, 83-105. http://dx.doi.org/10.1080/10511482.2002.9521436

[49] Grohe, B., DeValve, M. and Quinn, E. (2012) Is Perception Reality? The Comparison of Citizens' Levels of Fear of Crime versus Perception of Crime Problems in Communities. Crime Prevention and Community Safety, 14, $196-211$. http://dx.doi.org/10.1057/cpcs.2012.3

[50] Koskela, H. and Pain, R. (2000) Revisiting Fear and Place: Women’s Fear to Attack and the Built Environment. Geoforum, 31, 269-280. http://dx.doi.org/10.1016/S0016-7185(99)00033-0

[51] Mawby, R.I. (1977) Defensible Space: A Theoretical and Empirical Appraisal. Urban Studies, 14, 169-179. http://dx.doi.org/10.1080/00420987720080321

[52] Mayhew, P. (1979) Defensible Space: The Current Status of a Crime Prevention Theory. The Howard Journal of Criminal Justice, 18, 150-159. http://dx.doi.org/10.1111/j.1468-2311.1979.tb00389.x

[53] Steventon, G. (1996) Defensible Space: A Critical Review of the Theory and Practice of a Crime Prevention Strategy. 
Urban Design International, 1, 235-245. http://dx.doi.org/10.1057/udi.1996.31

[54] Ekblom, P. (2011) Deconstructing CPTED... and Reconstructing It for Practice, Knowledge Management and Research. European Journal on Criminal Policy and Research, 17, 7-28.

[55] Kearns, A. and Parkes, A. (2003) Living in and Leaving Poor Neighbourhood Conditions in England. Housing Studies, 18, 827-851. http://dx.doi.org/10.1080/0267303032000135456

[56] Lu, M. (1999) Determinants of Residential Satisfaction: Ordered Logit vs. Regression Models. Growth and Change, 30, 264-287. http://dx.doi.org/10.1111/0017-4815.00113

[57] Sirgy, M.J. and Cornwell, T. (2002) How Neighborhood Features Affect Quality of Life. Social Indicators Research, 59, 79-114. http://dx.doi.org/10.1023/A:1016021108513

[58] Woldoff, R.A. (2002) The Effects of Local Stressors on Neighborhood Attachment. Social Forces, 81, 87-116. http://dx.doi.org/10.1353/sof.2002.0065

[59] Clark, W.A.V. and Cadwallader, M. (1973) Residential Preferences: An Alternative View of Intraurban Space. Environment and Planning, 5, 693-703. http://dx.doi.org/10.1068/a050693

[60] Weinberg, D.H., Friedman, J. and Mayo, S.K. (1981) Intraurban Residential Mobility: The Role of Transactions Costs, Market Imperfections, and Household Disequilibrium. Journal of Urban Economics, 9, 332-348. http://dx.doi.org/10.1016/0094-1190(81)90031-0

[61] Newman, S.J. and Duncan, G.J. (1979) Residential Problems, Dissatisfaction and Mobility. Journal of the American Planning Association, 45, 154-162. http://dx.doi.org/10.1080/01944367908976953

[62] Landman, K. (2009) Boundaries, Bars, and Barricades: Reconsidering two Approaches to Crime Prevention in the Built Environment. Journal of Architectural and Planning Research, 26, 213-227.

[63] Atlas, R. (2008) Conducting a CPTED Survey. In: Atlas, R., Ed., 21st Century Security and CPTED: Designing for Critical Infrastructure Protection and Crime Prevention, CRC Press, Fort Lauderdale, 511-522.

[64] Jeffery, C.R. (1971) Crime Prevention through Environmental Design. Sage Publications, Beverly Hills.

[65] Kang, S.J. (2013) Crime Prevention in Ethnic Areas Focusing on Crime Prevention through Environmental Design. Journal of Building Construction and Planning Research, 1, 15-23. http://dx.doi.org/10.4236/jbcpr.2013.11003

[66] Newman, O. (1972) Defensible Space: Crime Prevention through Urban Design. Macmillan, New York.

[67] Merry, S.E. (1981) Defensible Space Undefended: Social Factors in Crime Control through Environmental Design. Urban Affairs Review, 16, 397-422. http://dx.doi.org/10.1177/107808748101600401

[68] Reynald, D.M. (2011) Translating CPTED into Crime Preventive Action: A Critical Examination of CPTED as a Tool for Active Guardianship. European Journal on Criminal Policy and Research, 17, 69-81. http://dx.doi.org/10.1007/s10610-010-9135-6

[69] Samuels, R. (2005) After-Dark Design, Night Animation, and Interpersonal Interaction: Toward a Community-Security Paradigm. Journal of Architectural and Planning Research, 22, 305-318.

[70] Painter, K. and Farrington, D.P. (1997) The Crime Reducing Effect of Improved Street Lighting: The Dudley Project. In: Clarke, R.V., Ed., Situational Crime Prevention-Successful Case Studies, 2nd Edition, Harrow and Heston, Guilderland, 209-226.

[71] Welsh, B.C. and Farrington, D.P. (2009) Making Public Places Safer: Surveillance and Crime Prevention. Oxford University Press, New York.

[72] McKay, T. (1996) A CPTED Case Study. Plan Canada, September/septembre, 39-40.

[73] Kelling, G.L. and Coles, C.M. (1996) Fixing Broken Windows: Restoring Order and Reducing Crime in Our Communities. Touchstone, Simon and Schuster, New York.

[74] Taylor, R.B., Gottfredson, S.D. and Brower, S. (1984) Block Crime and Fear: Defensible Space, Local Social Ties, and Territorial Functioning. Journal of Research in Crime and Delinquency, 21, 303-331. http://dx.doi.org/10.1177/0022427884021004003

[75] Atlas, R. (2008) Designing Safe Communities and Neighborhoods. In: Atlas, R., Ed., 21st Century Security and CPTED: Designing for Critical Infrastructure Protection and Crime Prevention, CRC Press, Fort Lauderdale, 255-278.

[76] Reynald, D.M. (2009) Guardianship in Action: Developing a New Tool for Measurement. Crime Prevention and Community Safety: An International Journal, 11, 1-20. http://dx.doi.org/10.1057/cpcs.2008.19

[77] Beavon, D.J.K., Brantingham, P.L. and Brantingham, P.J. (1994) The Influence of Street Networks on the Patterning of Property Offenses. In: Clarke, R.V., Ed., Crime Prevention Studies, Vol. 2, Criminal Justice Press, Monsey, 115-148.

[78] Plaut, P.O. and Plaut, S.E. (2010) Decisions to Renovate and to Move. Journal of Real Estate Research, 32, $461-484$.

[79] Thomsen, A. and van der Flier, K. (2009) Replacement or Renovation of Dwellings: The Relevance of a More Sus- 
tainable Approach. Building Research and Information, 37, 649-659. http://dx.doi.org/10.1080/09613210903189335

[80] Helms, A.C. (2003) Understanding Gentrification: An Empirical Analysis of the Determinants of Urban Housing Renovation. Journal of Urban Economics, 54, 474-498. http://dx.doi.org/10.1016/S0094-1190(03)00081-0

[81] Poyner, B. (2006) Crime-Free Housing in the 21st Century. Jill Dando Institute of Crime Science, University College London, London.

[82] Chang, D. (2011) Social Crime or Spatial Crime? Exploring the Effects of Social, Economical, and Spatial Factors on Burglary Rates. Environment and Behavior, 43, 26-52. http://dx.doi.org/10.1177/0013916509347728

[83] Hale, C. (1996) Fear of Crime: A Review of the Literature. International Review of Victimology, 4, 79-150. http://dx.doi.org/10.1177/026975809600400201

[84] Andresen, M.A. (2006) A Spatial Analysis of Crime in Vancouver, British Columbia: A Synthesis of Social Disorganization and Routine Activity Theory. The Canadian Geographer/Le Géographe Canadien, 50, 487-502. http://dx.doi.org/10.1111/j.1541-0064.2006.00159.x

[85] Kohm, S.A. (2009) Spatial Dimensions of Fear in a High-Crime Community: Fear of Crime or Fear of Disorder? Canadian Journal of Criminology and Criminal Justice, 51, 1-30. http://dx.doi.org/10.3138/cjccj.51.1.1

[86] Malczewski, J. and Poetz, A. (2005) Residential Burglaries and Neighbourhood Socioeconomic Context in London, Ontario: Global and Local Regression Analysis. The Professional Geographer, 57, 516-529. http://dx.doi.org/10.1111/j.1467-9272.2005.00496.x

[87] Nelson, A.L., Bromley, R.D.F. and Thomas, C.J. (2001) Identifying Micro-Spatial and Temporal Patterns of Violent Crime and Disorder in the British City Centre. Applied Geography, 21, 249-274. http://dx.doi.org/10.1016/S0143-6228(01)00008-X

[88] Weinrath, M., Clarke, K. and Forde, D.R. (2007) Trends in Fear of Crime in a Western Canadian City: 1984, 1994, and 2004. Canadian Journal of Criminology and Criminal Justice, 49, 617-646. http://dx.doi.org/10.3138/cjccj.49.5.617

[89] Wikström, P.O. and Dolmén, L. (1990) Crime and Crime Trends in Different Urban Environments. Journal of Quantitative Criminology, 6, 7-30. http://dx.doi.org/10.1007/BF01065287

[90] Cahill, M.E. and Mulligan, G.F. (2003) The Determinants of Crime in Tucson, Arizona. Urban Geography, 24, 582610.

[91] Mustaine, E.E. and Tewksbury, R. (1998) Predicting Risks of Larceny Theft Victimization: A Routine Activity Analysis Using Refined Lifestyle Measures. Criminology, 36, 829-857. http://dx.doi.org/10.1111/j.1745-9125.1998.tb01267.x

[92] Oh, J.H. (2003) Assessing the Social Bonds of Elderly Neighbors: The Roles of Length of Residence, Crime Victimization, and Perceived Disorder. Sociological Inquiry, 73, 490-510. http://dx.doi.org/10.1111/1475-682X.00068

[93] Robson, B., Lymperopoulou, K. and Rae, A. (2008) People on the Move: Exploring the Functional Roles of Deprived Neighbourhoods. Environment and Planning A, 40, 2693-2714. http://dx.doi.org/10.1068/a40241

[94] Carter, T. (1991) Neighbourhood Improvement: The Canadian Experience. In: Alterman, R. and Cars, G., Eds., Neighbourhood Regeneration: An International Experience, Mansell Publishing, London, 9-27.

[95] Larsen, K. (2005) New Urbanism’s Role in Inner-City Neighborhood Revitalization. Housing Studies, 20, $795-813$. Http://Dx.Doi.Org/10.1080/02673030500214068

[96] Stucky, T.D. and Ottensmann, J.R. (2009) Land Use and Violent Crime. Criminology, 47, 1223-1264. http://dx.doi.org/10.1111/j.1745-9125.2009.00174.x

[97] McIlroy, A. and Marland Bryan, R.M. (1996) Creating Safer Communities: Is Intensification the Answer? Plan Canada, 36, 20-23.

[98] McCord, E.S., Ratcliffe, J.H., Garcia, R.M. and Taylor, R.B. (2007) Nonresidential Crime Attractors and Generators Elevate Perceived Neighborhood Crime and Incivilities. Journal of Research in Crime and Delinquency, 44, 295-320. http://dx.doi.org/10.1177/0022427807301676

[99] Wilcox, P., Quisenberry, N., Cabrera, D.T. and Jones, S. (2004) Busy Places and Broken Windows? Toward Defining the Role of Physical Structure and Process in Community Crime Models. Sociological Quarterly, 45, 185-207. http://dx.doi.org/10.1111/j.1533-8525.2004.tb00009.x

[100] Grinols, E.L. and Mustard, D.B. (2006) Casinos, Crime and Community Costs. The Review of Economics and Statistics, 88, 28-45.

[101] Felson, M. (2002) Crime and Everyday Life. 3rd Edition, Sage Publications, Thousand Oaks.

[102] Roncek, D.W. and Maier, P.A. (1991) Bars, Blocks, and Crimes Revisited: Linking the Theory of Routine Activities to the Empiricism of “Hot Spots”. Criminology, 29, 725-753. http://dx.doi.org/10.1111/j.1745-9125.1991.tb01086.x 
[103] Dobchuk-Land, B., Toews, O. and Silver, J. (2010) Neighbourhood-Level Responses to Safety Concerns in Four Winnipeg Inner-City Neighbourhoods: Reflections on Collective Efficacy. Canadian Journal of Urban Research, 19, 1833.

[104] Sampson, R.J., Raudenbush, S.W. and Earls, F. (1997) Neighbourhoods and Violent Crime: A Multilevel Study of Collective Efficacy. Science, 277, 918-924. http://dx.doi.org/10.1126/science.277.5328.918

[105] Taylor, R.B. (1996) Neighborhood Responses to Disorder and Local Attachments: The Systemic Model of Attachment, Social Disorganization, and Neighborhood Use Value. Sociological Forum, 11, 41-74. http://dx.doi.org/10.1007/BF02408301

[106] Hanlon, B. (2008) The Decline of Older, Inner Suburbs in Metropolitan America. Housing Policy Debate, 19, $423-456$. http://dx.doi.org/10.1080/10511482.2008.9521642

[107] Kim, M.J. and Morrow-Jones, H.A. (2011) Intrametropolitan Residential Mobility and Older Inner Suburbs: A Case Study of the Greater Columbus, Ohio, Metropolitan Area. Housing Policy Debate, 21, 133-164. http://dx.doi.org/10.1080/10511482.2011.534390

[108] Rentschler, C.A. (2000) Designing Fear: Environmental Security and Violence against Women. Cultural Studies: A Research Annual, 5, 281-307.

[109] Wilson, J.Q. and Kelling, G.L. (1982) The Police and Neighbourhood Safety "Broken Windows". The Atlantic Monthly, 3, 29-38.

[110] Burby, R.J., Salvesen, D. and Creed, M. (2006) Encouraging Residential Rehabilitation with Building Codes: New Jersey's Experience. Journal of the American Planning Association, 72, 183-196.

http://dx.doi.org/10.1080/01944360608976738 
Scientific Research Publishing (SCIRP) is one of the largest Open Access journal publishers. It is currently publishing more than 200 open access, online, peer-reviewed journals covering a wide range of academic disciplines. SCIRP serves the worldwide academic communities and contributes to the progress and application of science with its publication.

Other selected journals from SCIRP are listed as below. Submit your manuscript to us via either submit@scirp.org or Online Submission Portal.
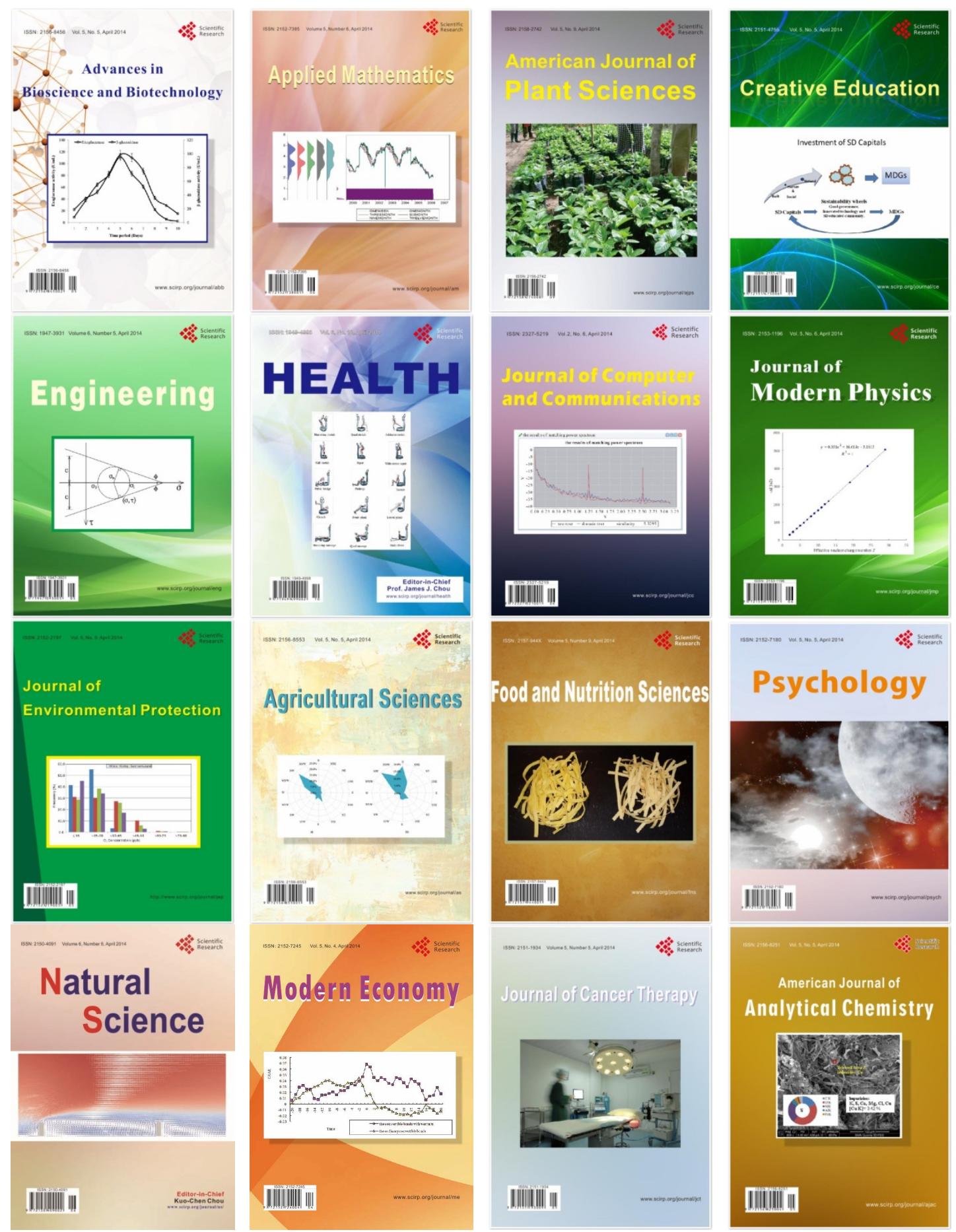